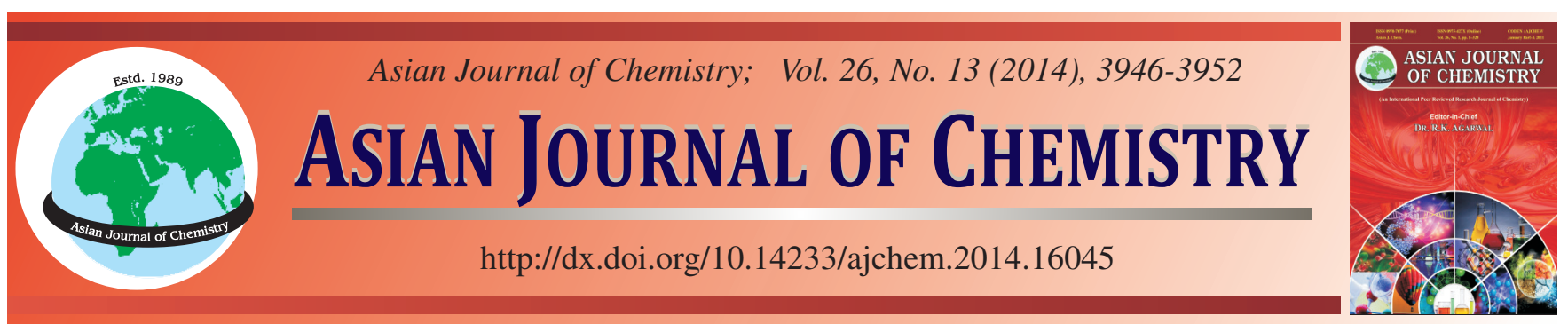

\title{
Determination of Natural Radioactivity Levels of Some Concretes and Mineral Admixtures in Turkey
}

\author{
Hasan Baltas ${ }^{1, *}$, Erkan Kiris ${ }^{1}$, Illker Ustabas ${ }^{2}$, Esra Yilmaz ${ }^{1}$, Murat Sirin $^{1}$, Emrah Kuloglu ${ }^{1}$ and Banu Erdogan Gunes ${ }^{1}$
}

${ }^{1}$ Department of Physics, Faculty of Art and Science, Recep Tayyip Erdogan University, 53100 Rize, Turkey

${ }^{2}$ Department of Structure, Vocational School, Recep Tayyip Erdogan University, 53100 Rize Turkey

*Corresponding author: Fax: +90 46 42235376; Tel: +90 46 42236126; E-mail: hasanbaltas01 @ hotmail.com

\begin{abstract}
Nine concrete samples with or without mineral admixtures have been analyzed for their naturally occurring radionuclide of ${ }^{226} \mathrm{Ra},{ }^{232} \mathrm{Th}$ and ${ }^{40} \mathrm{~K}$ using HPGe gamma spectrometry. Also, concrete raw materials such as aggregate, cement, fly ash and blast furnace slag have been measured. The radioactivity values of ${ }^{226} \mathrm{Ra},{ }^{232} \mathrm{Th}$ and ${ }^{40} \mathrm{~K}$ in fly ash and those of ${ }^{226} \mathrm{Ra}$ in blast furnace slag are higher than the corresponding world mean specific activities values which are 50,50 and $500 \mathrm{~Bq} \mathrm{~kg}^{-1}$ for ${ }^{226} \mathrm{Ra}^{232} \mathrm{Th}$ and ${ }^{40} \mathrm{~K}$, respectively. The concretes activity concentrations have been found to change with supplementary cementitious materials of the concrete samples. This may be attributed to containing different proportions of different mineral additives such as fly ash and blast furnace slag which were found to contain high natural radionuclide concentrations according to the rest of raw material samples. In addition, radium equivalent activities $\left(\operatorname{Ra}_{\text {eq }}\right), \gamma$-index $\left(\mathrm{I}_{\gamma}\right), \alpha$-index $\left(\mathrm{I}_{\alpha}\right)$, absorbed dose rate in air $(\mathrm{D})$ and annual effective dose associated with the natural radionuclide were calculated to assess the radiation hazard of the natural radioactivity in the concrete mixture samples. The concentration of the natural radionuclides and the radium equivalent activity obtained in the present study are compared with the previous results. From these results, it can be seen that these building materials do not pose significant radiation hazards.
\end{abstract}

Keywords: Natural radioactivity, Concrete, Fly ash, Blast furnace, Cement.

\section{INTRODUCTION}

In its most basic form, concrete is a mixture of portland cement, sand, coarse aggregates and water. The principle cementitious material in concrete is portland cement. Today, most concrete mixtures contain supplementary cementitious materials that make up a portion of the cementitious component in concrete. Supplementary cementitious materials such as fly ash and granule blast furnace slag enable the concrete industry to use hundreds of millions of tons of by product materials that would otherwise be used as land-filled as in the west ${ }^{1}$. In recent years fly ash and granule blast furnace have been used as a replacement of sand and cement in premixed concrete, manufacture of blended fly ash portland cement, aerated concrete, fly as clay bricks and blocks and for the filling of underground cavities etc. ${ }^{2}$. The building industry requires large quantities of low-cost materials and new products that may be substitutes for the widely used natural products as conventional building materials. However, such new building materials may contain significant quantities of naturally or technologically enhanced levels of radioactivity ${ }^{3}$. The presence of these radioisotopes in materials causes external exposure to people who live in the building ${ }^{4}$.
Natural radioactivity in concrete materials comes mainly from uranium $\left({ }^{238} \mathrm{U}\right)$ and thorium $\left({ }^{238} \mathrm{Th}\right)$ series and the radioactive isotopes of potassium $\left({ }^{40} \mathrm{~K}\right)$. In the uranium series, the decay chain segment starting from radium $\left({ }^{226} \mathrm{Ra}\right)$ is radiological the most important and, therefore, reference is often made to radium instead of uranium. The knowledge of natural radioactivity in these materials is then important for determining the amount of public exposure because people spend most of their time (about $80 \%$ ) indoors ${ }^{5}$. This knowledge is important in the assessment of possible radiological hazards to human health and essential for the development of standards and guidelines in using and these materials.

In the recent years, there has been an increasing interest in the study of radioactivity in various building and their raw materials $^{6-12}$.

The aim of this paper is to measure the natural activity concentrations of some concrete samples. The natural activity concentrations in two different types of concrete (MF and $\mathrm{MB}$ ) and their initial raw materials (fly ash and granule blast furnace slag) were also measured in order to assess each material's contribution to total concrete activity. The results obtained are compared with the results available in some other countries of the world. 


\section{EXPERIMENTAL}

The composition of the mortars all derive from the composition of standardized mortar (concrete) as specified in the TS EN 196-1 standard. All concrete is used in normalized sand CEN EN 196-1 and the ordinary Portland cement, CEM I 42.5 $\mathrm{R}$. This cement was mixed with two mineral additives; fly ash and granule blast furnace slag in some mortars. Concrete samples were prepared by Hobart mixer according to TS EN 196-1. Mortar was placed on the jolting Table is blocked in a mould to be $4 \mathrm{~cm} \times 4 \mathrm{~cm} \times 16 \mathrm{~cm}$. After $24 \mathrm{~h}$ of curing $20^{\circ} \mathrm{C}$ by 90 $\%$ relative humidity, the samples were removed from the molds and placed in standard curing condition in statured lime water at $20 \pm 1{ }^{\circ} \mathrm{C}$. Three main different concrete types were prepared. For the basic type, without mineral additives, "ordinary" concrete mixture (MO, $0 \%$ ) consists of $450 \mathrm{~g}$ cement, 1350 aggregate and $225 \mathrm{~g}$ water ( proportion 1:3:0.5 respectively). The other two types were produced by adding supplementary cementitious materials to the cement. In case of the fly ash and granule blast furnace slag concretes, respectively, (MF) and $(\mathrm{MB})$ were incorporated in the cementitious materials at proportions of 5, 10, 20 and $30 \%$ by weight. Finally, a total of nine concrete types were obtained. Again, all concrete mixtures have the same weight for total cementitious materials (cement and mineral additives) which equals to $450 \mathrm{~g}$. The compositions of the concretes were listed in Table- $1^{2}$.

Radioactivity measurements: Each sample was homogenized and dried in a temperature controlled furnace at $105^{\circ} \mathrm{C}$ for $24 \mathrm{~h}$ to remove moisture and sieved through a $2 \mathrm{~mm}$ mesh. About $120 \mathrm{~g}$ of samples were sealed in gas tight, radon impermeable, cylindrical polyethylene plastic containers (5.5 $\mathrm{cm}$ diameter and $5 \mathrm{~cm}$ height) for $\gamma$-activity analysis. Before measurements, the containers were kept sealed for 4 weeks in order to reach the equilibrium of ${ }^{226} \mathrm{Ra}$ and its short lived progeny.

Gamma spectrometry measurements were conducted with a coaxial HPGe detector of $55 \%$ relative efficiency and a resolution of $1.9 \mathrm{keV}$ at the $1332 \mathrm{keV}$ gamma of ${ }^{60} \mathrm{Co}$ (Ortec, GEM55P4-95 model). The detector was shielded in a $10 \mathrm{~cm}$ thick lead well internally lined with $2 \mathrm{~mm} \mathrm{Cu}$ foils. The spectrum analysis was performed using computer software Genie 2000 obtained from Ortec. A performance test using the certified reference samples (IAEA-375, IAEA, Vienna) of known activities was conducted for checking the efficiency calibration of the system. The specific activities of these samples were in accordance with their certified values within errors not exceeding $10 \%$. The quality assurance of the measurements was carried out by periodical efficiency and energy calibration and repeated sample measurement. The counting time for each sample was selected to be 50,000 to obtain the gamma-spectrum with good statistics. To determine the background distribution in the environment around the detector, an empty container was counted in the same manner and in the same geometry as the samples. The background spectra were used to correct the net peak area of $\gamma$-rays of the measured isotopes.

The $\gamma$-ray transitions of energies $351.9 \mathrm{keV}\left({ }^{214} \mathrm{~Pb}\right)$ and $609.3 \mathrm{keV}\left({ }^{214} \mathrm{Bi}\right)$ were used to determine the activity concentration of the ${ }^{226} \mathrm{Ra}$ series. The $\gamma$-ray lines at $911.1 \mathrm{keV}\left({ }^{228} \mathrm{Ac}\right)$ and $583.1 \mathrm{keV}\left({ }^{208} \mathrm{Tl}\right)$ were used to determine the activity concentration of the ${ }^{232} \mathrm{Th}$ series. The activity concentrations of ${ }^{40} \mathrm{~K}$ were measured directly through the gamma line emission at $1460.8 \mathrm{keV}$.

The activity concentrations for the natural radionuclides in the measured samples are computed using the following relation:

$$
\mathrm{C}=\frac{\mathrm{N}}{\varepsilon \mathrm{PMt}}\left(\mathrm{Bq} \mathrm{kg}^{-1}\right)
$$

where $\mathrm{N}$ is the net counting rate of the gamma ray, $\varepsilon$ is the photo peak efficiency of the used detector, $\mathrm{P}$ is the absolute transition of gamma decay, $t$ is the counting time in seconds and $\mathrm{M}$ the weight of the dried sample in kilogram.

Radium equivalent activity $\left(\mathbf{R} \mathbf{a}_{\mathrm{eq}}\right)$ : The distribution of ${ }^{226} \mathrm{Ra},{ }^{232} \mathrm{Th}$ and ${ }^{40} \mathrm{~K}$ in the concrete materials was not uniform. Uniformity with respect to exposure to radiation was defined in terms of radium equivalent activity $\left(\mathrm{Ra}_{\mathrm{eq}}\right)$ in $\mathrm{Bq} \mathrm{kg}^{-1}$ to compare the specific activity of materials containing different amounts of ${ }^{226} \mathrm{Ra},{ }^{232} \mathrm{Th}$ and ${ }^{40} \mathrm{~K}$. The radium equivalent activity is calculated through the following relation ${ }^{13}$ :

$$
\mathrm{Ra}_{\mathrm{eq}}=\mathrm{C}_{\mathrm{Ra}}+1.43 \mathrm{C}_{\mathrm{Th}}+0.077 \mathrm{C}_{\mathrm{K}}
$$

where $\mathrm{C}_{\mathrm{Ra}}, \mathrm{C}_{\mathrm{Th}}$ and $\mathrm{C}_{\mathrm{K}}$ are the activity concentrations of ${ }^{226} \mathrm{Ra}$, ${ }^{232} \mathrm{Th}$ and ${ }^{40} \mathrm{~K}$ in $\mathrm{Bq} \mathrm{kg}^{-1}$, respectively.

$\boldsymbol{\gamma}$-Index $\left(\mathbf{I}_{\gamma}\right)$ : Number of indices dealing with the assessment of the excess $\gamma$-radiation arising from building materials such as external and internal hazard indices and $\gamma$-concentration indices has been proposed by several investigators ${ }^{13-16}$. In this study, the $\gamma$-index $\left(\mathrm{I}_{\gamma}\right)$ is calculated as proposed by the European commission $^{14}$.

$$
\mathrm{I}_{\gamma}=\frac{\mathrm{C}_{\mathrm{Ra}}}{300}+\frac{\mathrm{C}_{\mathrm{Th}}}{200}+\frac{\mathrm{C}_{\mathrm{K}}}{3000}
$$

where $\mathrm{C}_{\mathrm{Ra}}, \mathrm{C}_{\mathrm{Th}}$ and $\mathrm{C}_{\mathrm{K}}$ are the activity concentrations of ${ }^{226} \mathrm{Ra}$, ${ }^{232} \mathrm{Th}$ and ${ }^{40} \mathrm{~K}$ in $\mathrm{Bq} \mathrm{kg}{ }^{-1}$, respectively.

$\boldsymbol{\alpha}$-Index $\left(\mathbf{I}_{\alpha}\right)$ : So far, several $\alpha$-indices have been proposed to assess the exposure level due to radon inhalation originating from building materials ${ }^{14}$. The $\alpha$-index is determined by the following formula:

$$
\mathrm{I}_{\alpha}=\frac{\mathrm{C}_{\mathrm{Ra}}}{200\left(\mathrm{~Bq} \mathrm{~kg}^{-1}\right)}
$$

where $\left.\mathrm{C}_{\mathrm{Ra}}(\mathrm{Bq} \mathrm{kg})^{-1}\right)$ is the activity concentration of ${ }^{226} \mathrm{Ra}$ assumed in equilibrium with ${ }^{238} \mathrm{U}$. The recommended exemption and upper level of ${ }^{226} \mathrm{Ra}$ activity concentrations in building materials are 100 and $200 \mathrm{~Bq} \mathrm{~kg}^{-1}$, respectively, as suggested by ICRP ${ }^{17}$. These considerations are reflected in the $\alpha$-index. The recommended upper limit concentration of ${ }^{226} \mathrm{Ra}$ is 200 $\mathrm{Bq} \mathrm{kg}^{-1}$, for which $\mathrm{I}_{\alpha}=1$.

Calculation of air-absorbed dose rates: There is concern that some of the buildings will cause excessive radiation doses to the total body due to $\gamma$-rays emitted by ${ }^{214} \mathrm{~Pb}$ and ${ }^{214} \mathrm{Bi}$ progeny of ${ }^{226} \mathrm{Ra}$ and ${ }^{232} \mathrm{Th}$ decay chains and ${ }^{40} \mathrm{~K}$ also contributes to the total body radiation dose. The absorbed dose rate in indoor air due to $\gamma$-ray emission from activity concentrations of ${ }^{226} \mathrm{Ra},{ }^{232} \mathrm{Th}$ and ${ }^{40} \mathrm{~K}$ is estimated using the following formula provided by UNSCEAR ${ }^{18}$ and $\mathrm{EC}^{14}$.

$$
\mathrm{D}=\alpha \mathrm{C}_{\mathrm{Ra}}+\beta \mathrm{C}_{\mathrm{Th}}+\gamma \mathrm{C}_{\mathrm{K}}
$$


where $\alpha, \beta$ and $\gamma$ are the dose rates per unit activity concentrations of $\mathrm{Ra}$, Th and $\mathrm{K}\left(\mathrm{nGy} \mathrm{h}^{-1} / \mathrm{Bq} \mathrm{kg}^{-1}\right) ; \mathrm{C}_{\mathrm{Ra}}, \mathrm{C}_{\mathrm{Th}}$ and $\mathrm{C}_{\mathrm{K}}$ are the activity concentrations of $\mathrm{Ra}$, Th and $\mathrm{K}\left(\mathrm{Bq} \mathrm{kg}^{-1}\right)$, respectively. The values of $\alpha, \beta$ and $\gamma$ were taken to be 0.92 , 1.1 and 0.08 , respectively ${ }^{14}$.

Calculation of the annual effective dose: To estimate the annual effective dose, it must be taken into account: (a) the conversion coefficient $\left(0.7 \mathrm{~Sv} \mathrm{~Gy}^{-1}\right)$ from absorbed dose in air to effective dose and (b) the indoor occupancy factor (about $80 \%$ for Turkish population). Therefore, the effective dose rate in $\mathrm{mSv}^{-1}$ unit is estimated by the following formula ${ }^{19}$ :

$$
\begin{gathered}
\operatorname{AED}\left(\mathrm{mSv} \mathrm{y}^{-1}\right)=\mathrm{D}\left(\mathrm{nGy} \mathrm{h}^{-1}\right) \times 8760 \mathrm{~h} \mathrm{y}^{-1} \\
\times 0.7 \times 0.8 \times 10^{-6}
\end{gathered}
$$

\section{RESULTS AND DISCUSSION}

The composition (in gram) of the nine concrete mixtures is summarized in Table-1. In Turkey, these types of concretes are commonly used as building material. The results of activity concentrations are given in Table- 2 for the natural radionuclides of ${ }^{226} \mathrm{Ra},{ }^{232} \mathrm{Th}$ and ${ }^{40} \mathrm{~K}$ in ordinary concrete MO and concretes loaded with different proportions of different mineral additives (MF and MB). It can also be seen from Table-2 that the results increase with increasing percentage of additions for concrete mixture samples. When the concrete mixture samples were compared in their own right, it was observed that the ${ }^{226} \mathrm{Ra},{ }^{232} \mathrm{Th}$ and ${ }^{40} \mathrm{~K}$ activity concentrations of concrete mixture samples increase with the addition of fly ash and blast furnace slag at percentages of $0,5,10,20$ and $30 \%$ as shown Fig. 1. The specific activities values obtained in this study were found to be lower than recommended maximum level for all mixture concrete samples ${ }^{20}$.

TABLE-1 COMPOSITION (g) OF THE NINE CONCRETE MIXTURES

\begin{tabular}{ccccccc}
\hline Mortars & $(\%)$ & Cement & Water & Fly ash & $\begin{array}{c}\text { Blast } \\
\text { furnace } \\
\text { slag }\end{array}$ & Aggregate \\
\hline MO & 0 & 450 & 225 & 0 & 0 & 1350 \\
MF5 & 5 & 427.5 & 225 & 22.5 & 0 & 1350 \\
MF10 & 10 & 405 & 225 & 45 & 0 & 1350 \\
MF20 & 20 & 360 & 225 & 90 & 0 & 1350 \\
MF30 & 30 & 315 & 225 & 135 & 0 & 1350 \\
MB5 & 5 & 427.5 & 225 & 0 & 22.5 & 1350 \\
MB10 & 10 & 405 & 225 & 0 & 45 & 1350 \\
MB20 & 20 & 360 & 225 & 0 & 90 & 1350 \\
MB30 & 30 & 315 & 225 & 0 & 135 & 1350 \\
\hline
\end{tabular}
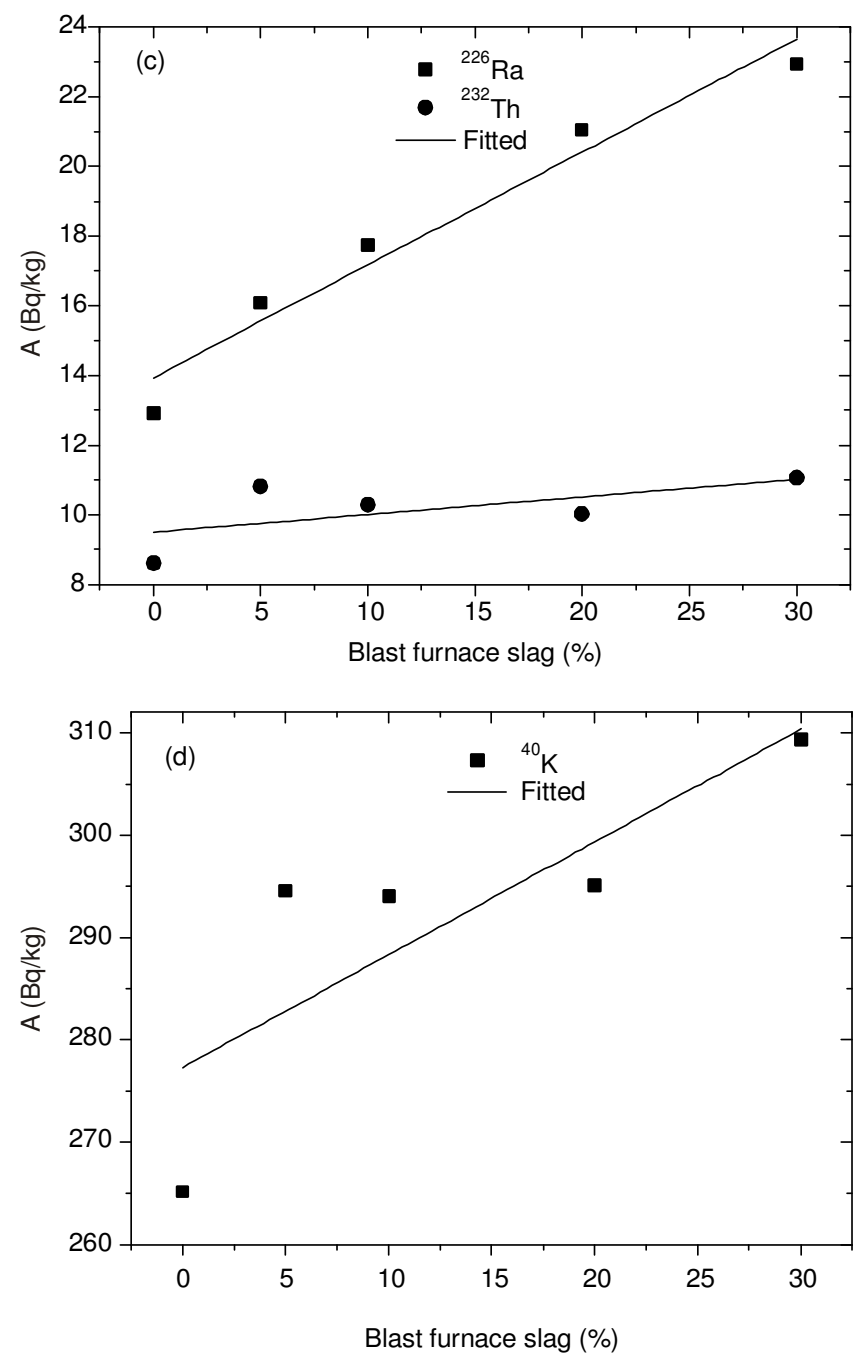

Fig. 1. Activity concentrations in concrete mixture samples versus per cent of values of fly ash (a, b) and blast furnace slag (c, d) 


\begin{tabular}{|c|c|c|c|}
\hline \multicolumn{4}{|c|}{$\begin{array}{c}\text { TABLE-2 } \\
\text { ACTIVITY CONCENTRATIONS }\left(\mathrm{Bq} \mathrm{kg}^{-1}\right) \mathrm{OF}^{232} \mathrm{Th}^{226} \mathrm{Ra}^{20 N D}{ }^{40} \mathrm{~K} \\
\text { IN CONCRETE SAMPLES ACCORDING TO THE DIFFERENT } \\
\text { PERCENTAGES AND CONCRETE RAW MATERIALS }\end{array}$} \\
\hline \multirow{2}{*}{ Samples } & \multicolumn{3}{|c|}{ Radionuclide concentrations $(\mathrm{Bq} / \mathrm{kg})$} \\
\hline & ${ }^{226} \mathrm{Ra}$ & ${ }^{232} \mathrm{Th}$ & ${ }^{40} \mathrm{~K}$ \\
\hline $\mathrm{MO}$ & $12.91 \pm 0.59$ & $8.61 \pm 0.73$ & $265.18 \pm 7.02$ \\
\hline MF5 & $14.90 \pm 0.65$ & $10.18 \pm 0.82$ & $282.06 \pm 7.49$ \\
\hline MF10 & $15.81 \pm 0.67$ & $10.30 \pm 0.83$ & $291.97 \pm 7.68$ \\
\hline MF20 & $17.53 \pm 0.70$ & $13.19 \pm 0.88$ & $305.16 \pm 7.83$ \\
\hline MF30 & $20.78 \pm 0.79$ & $15.32 \pm 1.00$ & $337.45 \pm 8.71$ \\
\hline MB5 & $16.08 \pm 0.73$ & $10.81 \pm 0.89$ & $294.55 \pm 8.20$ \\
\hline MB10 & $17.74 \pm 0.69$ & $10.29 \pm 0.88$ & $294.02 \pm 7.92$ \\
\hline MB20 & $21.06 \pm 0.75$ & $10.03 \pm 0.79$ & $295.05 \pm 7.29$ \\
\hline MB30 & $22.95 \pm 0.74$ & $11.06 \pm 0.87$ & $309.32 \pm 8.10$ \\
\hline Aggregate & $9.51 \pm 0.49$ & $8.00 \pm 0.65$ & $322.91 \pm 7.37$ \\
\hline Fly ash & $114.67 \pm 2.08$ & $87.86 \pm 2.71$ & $898.29 \pm 16.41$ \\
\hline Blast furnace slag & $186.69 \pm 2.38$ & $35.87 \pm 1.67$ & $295.91 \pm 9.08$ \\
\hline Cement & $26.09 \pm 0.83$ & $8.40 \pm 0.83$ & $168.42 \pm 5.76$ \\
\hline
\end{tabular}

In addition, the natural radionuclide concentrations of concretes 'raw materials such as cement, fly ash, blast furnace slag and aggregate were listed in Table-2. It is observed that the measured activity concentration values of ${ }^{226} \mathrm{Ra},{ }^{232} \mathrm{Th}$ and ${ }^{40} \mathrm{~K}$ in fly ash, blast furnace slag and ${ }^{40} \mathrm{~K}$ in aggregate are higher according to the other raw samples. As can be seen from Table-2, the radioactivity values of ${ }^{226} \mathrm{Ra},{ }^{232} \mathrm{Th}$ and ${ }^{40} \mathrm{~K}$ in fly ash and those of ${ }^{226} \mathrm{Ra}$ in blast furnace slag are higher than the corresponding world mean specific activities values which are 50, 50 and $500 \mathrm{~Bq} \mathrm{~kg}^{-1}$ for ${ }^{226} \mathrm{Ra},{ }^{232} \mathrm{Th}$ and ${ }^{40} \mathrm{~K}$, respectively ${ }^{20}$. Fly ash and blast furnace seems to be problematic from radionuclides content point of view. However, fly ash is used in Turkish cement industry as an addition to Portland-fly ash cement in an amount not exceeding $35 \%(6-35 \%)^{21}$. As a result, the natural activities values of the above-mentioned radionuclides in ordinary concrete $(\mathrm{MO})$, concretes loaded with different proportions of different mineral additives (MF and $\mathrm{MB})$, cement and aggregate are lower than the world mean values. From the point of view radionuclide, the mixing of fly ash and blast furnace slag with concrete components prepared in this work is suitable for the walls of the new buildings.

The mean calculated $\mathrm{Ra}_{\mathrm{eq}}$ values are shown in Table- 3 for the MO, MF and MB and for building raw materials (fly ash, blast furnace, cement and aggregate). The mean $\mathrm{Ra}_{\mathrm{eq}}$ values varies from $45.64 \pm 2.40$ to $68.67 \pm 2.89 \mathrm{~Bq} \mathrm{~kg}^{-1}, 45.64 \pm 2.63$
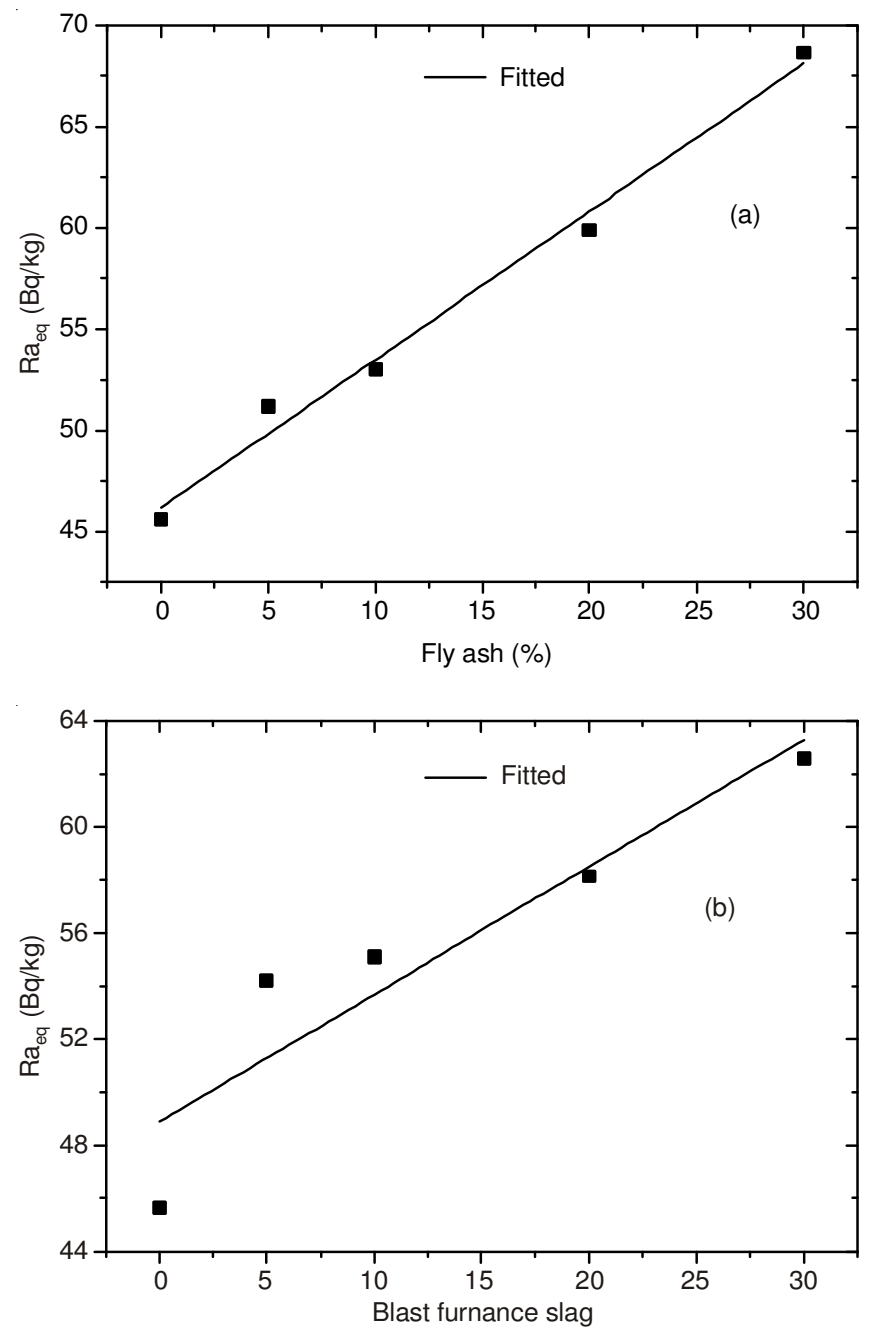

Fig. 2. Radium equivalent $\left(\mathrm{Ra}_{\mathrm{eq}}\right)$ activities in concrete mixture samples versus per cent of values of fly ash (a) and blast furnace slag (b)

to $62.58 \pm 2.61 \mathrm{~Bq} \mathrm{~kg}^{-1}$ for $\mathrm{MF}$ and $\mathrm{MB}$, respectively. It can be seen that the highest mean values of $\mathrm{Ra}_{\text {eq }}$ activity were determined in fly ash $\left(309.48 \pm 7.22 \mathrm{~Bq} \mathrm{~kg}^{-1}\right)$ and blast furnace $\left(260.77 \pm 5.47 \mathrm{~Bq} \mathrm{~kg}^{-1}\right)$. However, the obtained results indicate that the mean $\mathrm{Ra}_{\mathrm{eq}}$ values in this work are less than the recommended maximum levels for building materials to be used for house, which is $<370 \mathrm{~Bq} \mathrm{~kg}{ }^{-18,19,21,22}$. The results were also shown graphically in Fig. 2 for concrete mixture samples

TABLE 3

RADIUM EQUIVALENT ACTIVITY, $\gamma$-INDICES, $\alpha$-INDICES, THE DOSE RATE AND ANNUAL EFFECTIVE DOSE FOR CONCRETE SAMPLES ACCORDING TO THE DIFFERENT PERCENTAGES AND CONCRETE RAW MATERIALS

\begin{tabular}{|c|c|c|c|c|c|}
\hline Samples & $\mathrm{Ra}_{\mathrm{eq}}(\mathrm{Bq} / \mathrm{kg})$ & $\mathrm{I}_{\gamma}$ & $\mathrm{I}_{\alpha}$ & $\mathrm{D}\left(\mathrm{nGy} \mathrm{h}^{-1}\right)$ & $\operatorname{AED}\left(\mathrm{mSv}^{-1}\right)$ \\
\hline MO & $45.64 \pm 2.17$ & 0.17 & 0.06 & $42.56 \pm 1.91$ & 0.21 \\
\hline MF5 & $51.18 \pm 2.40$ & 0.19 & 0.07 & $47.47 \pm 2.10$ & 0.23 \\
\hline MF10 & $53.02 \pm 2.45$ & 0.20 & 0.08 & $49.23 \pm 2.14$ & 0.24 \\
\hline MF20 & $59.89 \pm 2.56$ & 0.23 & 0.09 & $55.05 \pm 2.24$ & 0.27 \\
\hline MF30 & $68.67 \pm 2.89$ & 0.26 & 0.10 & $62.97 \pm 2.52$ & 0.31 \\
\hline MB5 & $54.22 \pm 2.63$ & 0.21 & 0.08 & $50.25 \pm 2.31$ & 0.25 \\
\hline MB10 & $55.09 \pm 2.56$ & 0.21 & 0.09 & $51.16 \pm 2.24$ & 0.25 \\
\hline MB20 & $58.12 \pm 2.44$ & 0.22 & 0.11 & $54.01 \pm 2.14$ & 0.26 \\
\hline MB30 & $62.58 \pm 2.61$ & 0.23 & 0.11 & $58.03 \pm 2.29$ & 0.28 \\
\hline Aggregate & $45.81 \pm 1.99$ & 0.18 & 0.05 & $43.38 \pm 1.76$ & 0.21 \\
\hline Fly ash & $309.48 \pm 7.22$ & 1.12 & 0.57 & $274.01 \pm 6.21$ & 1.34 \\
\hline Blast furnace slag & $260.77 \pm 5.47$ & 0.90 & 0.93 & $234.88 \pm 4.75$ & 1.15 \\
\hline Cement & $51.07 \pm 2.46$ & 0.19 & 0.13 & $46.72 \pm 2.14$ & 0.23 \\
\hline
\end{tabular}


TABLE-4

COMPARISON OF ACTIVITY CONCENTRATIONS $\left(\mathrm{Bq} \mathrm{kg}^{-1}\right)$ AND THE RADIUM EQUIVALENT $\left(\mathrm{Ra}_{\mathrm{eq}}\right)$

ACTIVITIES WITH PUBLISHED RESULTS IN CEMENT (A), FLY ASH (B), BLAST FURNACE SLAG (C), AGGREGATE (D) AND CONCRETE (E) SAMPLES FROM DIFFERENT COUNTRIES

\begin{tabular}{|c|c|c|c|c|c|}
\hline \multirow{2}{*}{ Countries } & \multicolumn{3}{|c|}{ Radionuclide concentrations $\left(\mathrm{Bq} \mathrm{kg}^{-1}\right)$} & \multirow{2}{*}{$\mathrm{Ra}_{\mathrm{eq}}\left(\mathrm{Bq} \mathrm{kg}^{-1}\right)$} & \multirow{2}{*}{ References } \\
\hline & ${ }^{226} \mathrm{Ra}$ & ${ }^{232} \mathrm{Th}$ & ${ }^{40} \mathrm{~K}$ & & \\
\hline \multicolumn{6}{|c|}{ (a) Cement } \\
\hline Australia & 52 & 48 & 115 & 129 & [14] \\
\hline Austria & 27 & 14 & 210 & 63 & [23] \\
\hline Algeria & 41 & 27 & 422 & 112 & [24] \\
\hline Bangladesh & 61 & 80 & 1133 & 262 & [25] \\
\hline China & 57 & 37 & 173 & 122 & [26] \\
\hline Cameroon & $27^{\mathrm{a}}$ & 15 & 277 & 70.1 & [27] \\
\hline Cuba & 23 & 11 & 467 & 74 & [28] \\
\hline Egypt & 78 & 33 & 337 & 151 & [29] \\
\hline Finland & 40 & 20 & 251 & 88 & [30] \\
\hline Greece & 63 & 24 & 284 & 117 & [31] \\
\hline Italy & 38 & 22 & 218 & 92 & [32] \\
\hline Isparta, Turkey & 26.1 & 10.4 & 129.7 & 51.03 & [7] \\
\hline India & $98^{\mathrm{a}}$ & 81 & 340 & 240 & [33] \\
\hline Japan & 36 & 21 & 139 & 77 & [34] \\
\hline Malaysia & 81 & 59 & 203 & 181 & [35] \\
\hline Netherlands & 27 & 19 & 230 & 72 & [36] \\
\hline Pakistan & 26 & 29 & 273 & 88 & [37] \\
\hline Turkey & 41 & 26 & 267 & 98 & [21] \\
\hline Xianyang, China & 51.7 & 32 & 207.7 & 113.5 & [11] \\
\hline Turkey & 26.09 & 8.40 & 168.42 & 51.07 & Present study \\
\hline \multicolumn{6}{|c|}{ (b) Fly ash } \\
\hline Greece & 1377 & 65 & 661 & - & [10] \\
\hline Greece & 1041 & 55 & 462 & - & [8] \\
\hline India & 45.1 & 39.9 & 88.4 & 109.2 & [3] \\
\hline Israel & 202.0 & 62.9 & 377.7 & 321.0 & [5] \\
\hline Spain & 160 & 62.3 & 459.1 & - & [38] \\
\hline Turkey & 232.3 & 117.1 & 466.2 & 428.7 & [21] \\
\hline Turkey & 114.67 & 87.86 & 898.29 & 309.48 & Present study \\
\hline \multicolumn{6}{|c|}{ (c) Blast furnace slag } \\
\hline Egypt & 323 & 39.8 & 158 & 392.3 & [39] \\
\hline India & 67.3 & 77.7 & 145.1 & 189.8 & [3] \\
\hline Spain & 166.6 & 47.6 & 232.3 & - & [38] \\
\hline Turkey & 177.9 & 147.8 & 242.5 & 392.95 & [21] \\
\hline Turkey & 186.69 & 35.87 & 295.91 & 260.77 & Present study \\
\hline \multicolumn{6}{|c|}{ (d) Aggregate } \\
\hline Algeria & 24 & 10 & 259 & 58 & [24] \\
\hline Bangladesh & 248 & 219 & 389 & - & {$[40]$} \\
\hline Bangladesh & $25.26^{\mathrm{a}}$ & 54.71 & 228.4 & 121.29 & [41] \\
\hline Brazil & 10.3 & - & 933 & 82.1 & [42] \\
\hline Cuba & 20 & 13 & 134 & 49 & [28] \\
\hline Egypt & $9.8^{\mathrm{a}}$ & 3.5 & 62.4 & 19.7 & [39] \\
\hline Greece & 11 & 12 & 140 & 38.9 & [6] \\
\hline Israel & 15 & 3 & 50.4 & 23.2 & [5] \\
\hline Isparta, Turkey & 22.5 & 6.8 & 101.7 & 40.03 & [7] \\
\hline $\begin{array}{l}\text { Logbadjeck, } \\
\text { Cameroon }\end{array}$ & $24^{\mathrm{a}}$ & 139 & 1161 & 312.51 & [27] \\
\hline Ombe, Cameroon & $19.4^{\mathrm{a}}$ & 26 & 304 & 80.12 & [27] \\
\hline Pakistan & $33^{\mathrm{a}}$ & 32 & 57 & - & [43] \\
\hline Turkey & 21.6 & 25.8 & 482.2 & - & [44] \\
\hline Xi'an, China & 28.5 & 19.5 & 286.7 & 82.6 & [45] \\
\hline Xianyang, China & 19.9 & 22.5 & 413.0 & 84.0 & [11] \\
\hline Turkey & 9.51 & 8.00 & 322.91 & 45.81 & Present study \\
\hline \multicolumn{6}{|c|}{ (e) Concrete } \\
\hline Brazil & 14.8 & 9.9 & 361 & 56.7 & [42] \\
\hline Cuba & 25 & 12 & 595 & 87 & [28] \\
\hline Greece & 35 & 17 & 383 & 88.8 & [6] \\
\hline Egypt & 19.1 & 8.1 & 76.4 & 36.6 & [39] \\
\hline Egypt & 11.0 & 2.8 & 19.6 & 16.5 & [46] \\
\hline Ibadan, Nigeria & 24.5 & 37.3 & 354.4 & 105.2 & [47] \\
\hline Jos Nigeria & 66 & 126 & 589 & 292 & [48] \\
\hline Malaysia & $30^{\mathrm{a}}$ & 24 & 740 & 121 & [49] \\
\hline Xi'an, China & 46.2 & 28.4 & 137.4 & 98.6 & [45] \\
\hline Xianyang, China & 25.8 & 26.8 & 553.6 & 106.7 & [11] \\
\hline Turkey & 12.91 & 8.61 & 265.18 & 45.64 & Present study \\
\hline
\end{tabular}



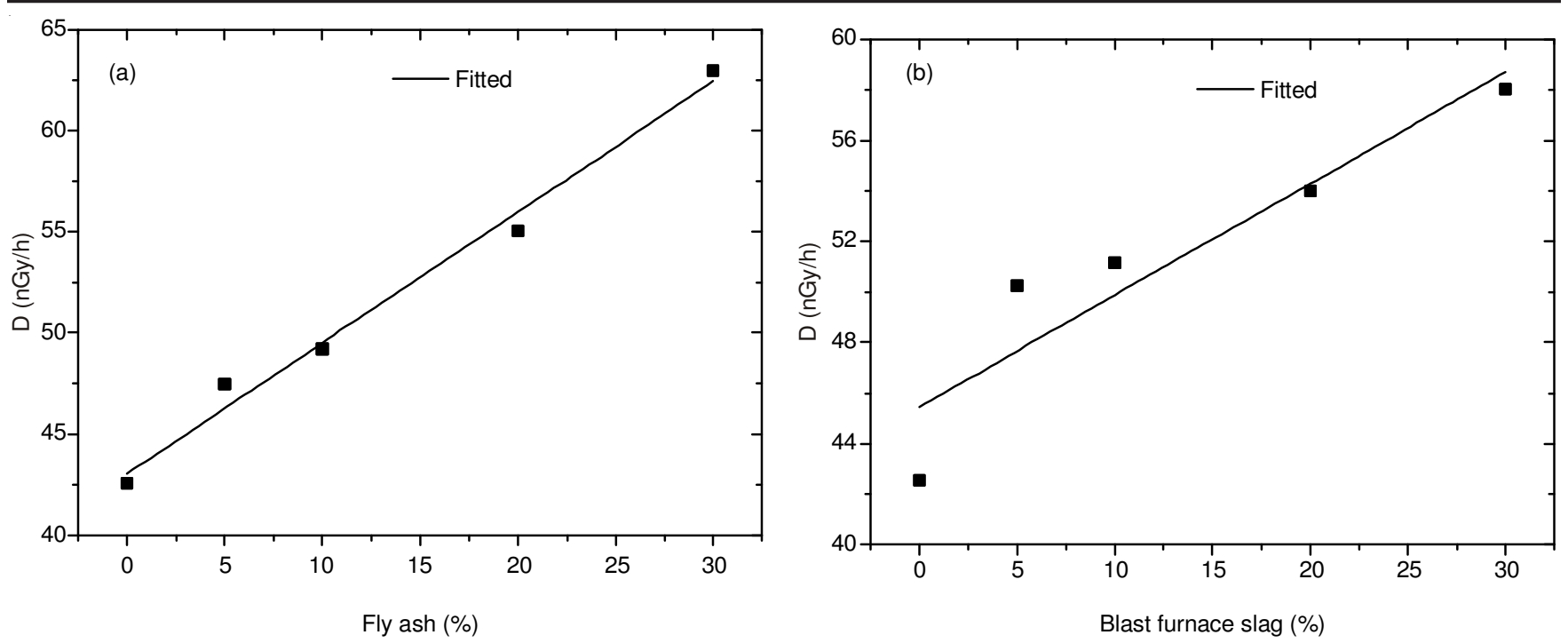

Fig. 3. Dose rate (D) values in concrete mixture samples versus per cent of values of fly ash (a) and blast furnace slag (b)

versus per cent of values of fly ash and blast furnace slag, respectively. Fig. 2 demonstrate same noticed feature in previous figure, such as increasing of radium equivalents with mineral additives. Table-4a-e lists the comparison between activity concentrations and radium equivalents $\left(\mathrm{Bq} \mathrm{kg}^{-1}\right)$ in cement, fly ash, blast furnace, aggregate and concrete in different areas of the world, respectively. The comparison shows a reasonable agreement for cement, blast furnace slag, aggre-gate and mixture concretes samples in Table-4a, c, d, e, respectively. As shown in Table-4b, if we compare our results with those of values in different countries for fly ash, it is clear that ${ }^{226} \mathrm{Ra},{ }^{232} \mathrm{Th}$ and $\mathrm{Ra}_{\mathrm{eq}}$ is good agreement, while ${ }^{40} \mathrm{~K}$ is high in the present work.

The mean values of $\gamma$-index $\left(\mathrm{I}_{\gamma}\right)$ calculated from the measured activity concentration of ${ }^{226} \mathrm{Ra},{ }^{232} \mathrm{Th}$ and ${ }^{40} \mathrm{~K}$ are listed in Table-3 (column 2) for all the studied samples. It is observed that the mean $\gamma$-index $\mathrm{I}_{\gamma}$ values do not exceed critical value of unity for all samples. These values of $\mathrm{I}_{\gamma}$ are $<2$, which corresponds to a dose criterion of $0.3 \mathrm{mSv} \mathrm{y}^{-1}$. It is observed that mean $\mathrm{I}_{\gamma}$ of values for fly ash (1.12) and blast furnace slag (0.90) samples are higher than the values of the rest of the building raw materials and, the concrete mixture samples.

The $\alpha$-index $\left(\mathrm{I}_{\alpha}\right)$ was calculated from eqn. (4) and listed in Table-3 (column 3). As shown in Table-3, the calculated values of $\mathrm{I}_{\alpha}$ for the studied samples are less than unity.

The estimated absorbed dose rate (D) values for the studied samples are also shown in Table-3 (column 4). All the samples measured, except for fly ash $(274.01 \pm 6.21)$ and blast furnace slag $(234.88 \pm 4.75)$, showed values below the recommended upper level, which is $84 \mathrm{nGy} \mathrm{h}^{-1}$.

The obtained annual effective dose rate results are in Table-3 (column 5) and displayed in Fig. 3. The annual effective dose values for all samples except for fly ash $(1.34$ $\left.\mathrm{mSv} \mathrm{y}^{-1}\right)$ and blast furnace slag $\left(1.15 \mathrm{mSv}^{-1}\right)$ are lower than the limit value, which is $0.46 \mathrm{mSv} \mathrm{y}^{-118}$.

\section{Conclusion}

The specific activity of ${ }^{226} \mathrm{Ra},{ }^{232} \mathrm{Th}$ and ${ }^{40} \mathrm{~K}$ have been measured in ordinary concrete $\mathrm{MO}$, concretes loaded with different proportions of different mineral additives (MF and $\mathrm{MB}$ ) and building raw materials used in Turkey, using HPGe gamma spectrometry. The radioactivity values of ${ }^{226} \mathrm{Ra},{ }^{232} \mathrm{Th}$ and ${ }^{40} \mathrm{~K}$ in fly ash and those of ${ }^{226} \mathrm{Ra}$ in blast furnace slag are higher than the corresponding world mean specific activities values, while the rest of the samples are less than the critical value of unity. In addition, the mean radium equivalent activity $\left(\mathrm{Ra}_{\mathrm{eq}}\right), \gamma$-index $\left(\mathrm{I}_{\gamma}\right), \alpha$-index $\left(\mathrm{I}_{\alpha}\right)$, the indoor absorbed dose rate (D) and annual effective dose rate have been calculated for all samples. The observed these values except for annual effective dose values of fly ash and blast furnace slag are lower than the acceptable level. According to these results, mixture concrete samples examined in this study do not pose any significant source of radiation hazard and thus these materials could be safely used in building constructions.

\section{REFERENCES}

1. E. Yilmaz, H. Baltas, E. Kiris, I. Ustabas, U. Cevik and A.M. El-Khayatt, Ann. Nucl. Energy, 38, 2204 (2011).

2. V. Kumar, T.V. Ramachandran and R. Prasad, Appl. Radiat. Isot., 51, 93 (1999).

3. O. Baykara, S. Karatepe and M. Dogru, Radiat. Meas., 46, 153 (2011).

4. N. Kovler, G. Haquin, V. Manasherov, E. Ne'eman and N. Lavi, Build. Environ., 37, 531 (2002).

5. S. Stoulos, M. Manolopoulou and C. Papastefanou, J. Environ. Radioact., 69, 225 (2003).

6. B. Mavi and I. Akkurt, Radiat. Phys. Chem., 79, 933 (2010).

7. H. Papaefthymiou and O. Gouseti, Radiat. Meas., 43, 1453 (2008).

8. R. Hewamanna, C.S. Sumithrarachchi, P. Mahawatte, H.L.C. Nanayakkara and H.C. Ratnayake, Appl. Radiat. Isot., 54, 365 (2001).

9. N.P. Petropoulos, M.J. Anagnostakis and S.E. Simopoulos, J. Environ. Radioact., 61, 257 (2002).

10. X. Lu, G. Yang and C. Ren, Radiat. Phys. Chem., 81, 780 (2012).

11. U. Cevik, N. Damla, A.I. Kobya, A. Celik and A. Kara, Ann. Nucl. Energy, 37, 1705 (2010).

12. N. Damla, U. Cevik, A.I. Kobya, A. Celik, N. Celik and I. Yildirim, Radiat. Meas., 46, 701 (2011).

13. J. Beretka and P.J. Mathew, Health Phys., 48, 87 (1985).

14. European Commission (EC), Radiation Protection 112. Radiological Protection Principles Concerning the Natural Radioactivity of Building Materials, Directorate-General Environment, Nuclear Safety and Civil Protection (1999). 
15. Organization for Economic Cooperation and Development (OECD), Exposure to Radiation from the Natural Radioactivity in Building Materials, Report by a Group of Experts of the OECD Nuclear Energy Agency (1979).

16. V.R. Krieger, Betonwerk Fertigteil Tech., 47, 468 (1981).

17. ICRP, Protection against Rn-222 at home and at work. Publication No. 65; Ann. ICRP 23 (2), Pergamon, Oxford (1994).

18. United Nations Scientific Committee on the Effects of Atomic Radiation (UNSCEAR), Sources and Effects of Ionizing Radiation, Report of the United Nations Scientific Committee on the Effects of Atomic Radiation to the General Assembly, United Nations, New York, USA (2000).

19. N. Damla, U. Cevik, A.I. Kobya, A. Celik, N. Celik and R. Van Grieken, J. Hazard. Mater., 176, 644 (2010).

20. United Nations Scientific Committee on the effects of Atomic Radiation (UNSCEAR), Ionizing Radiation: Sources and Biological Effects, United Nations, New York (1993).

21. S. Turhan, J. Environ. Radioact., 99, 404 (2008).

22. M.O. Oresegun and A.I. Babalola, Annual Indoor Dose Burden Estimates in Dwellings Built in Nigeria with Radioactive U-Th Rich Tailings, Proceedings of an International Conference on Radiation Protection in Nuclear Energy, IAEA, Vienna, Austria 18-22 April, vol. 2, p. 159 (1988).

23. P. Sorantin and F. Steger, Radiat. Prot. Dosimetry, 7, 59 (1984).

24. D. Amrani and M. Tahtat, Appl. Radiat. Isot., 54, 687 (2001).

25. S. Roy, M.S. Alam, M. Begum and B. Alam, Radiat. Prot. Dosimetry, 114, 527 (2005).

26. L. Xinwei, Health Phys., 88, 84 (2005).

27. M. Ngachin, M. Garavaglia, C. Giovani, M.G. Kwato Njock and A. Nourreddine, Radiat. Meas., 42, 61 (2007).

28. O. Brígido Flores, A. Montalván Estrada, R. Rosa Suárez, J. Tomás Zerquera and A. Hernández Pérez, J. Environ. Radioact., 99, 1834 (2008).

29. E.M. El Afifi, M.A. Hilal, S.M. Khalifa and H.F. Aly, Radiat. Meas.,
41, 627 (2006).

30. R. Mustonen, Health Phys., 46, 1195 (1984).

31. C. Papastefanou, S. Stoulos and M. Manolopoulou, J. Radioanal. Nucl. Chem., 266, 367 (2005).

32. S. Rizzo, M. Brai, S. Basile, S. Bellia and S. Hauser, Appl. Radiat. Isot., 55, 259 (2001).

33. R.G. Sonkawade, K. Kant, S. Muralithar, R. Kumar and R.C. Ramola, Atmos. Environ., 42, 2254 (2008).

34. A. Suzuki, T. Iida, J. Moriizumi and Y. Sakuma, Radiat. Prot. Dosimetry, 90, 437 (2000).

35. C.S. Chong and G.U. Ahmed, Health Phys., 43, 272 (1982).

36. J.G. Ackers, J.F. Den Boer, P. De Jong and R.A. Wolschrijn, Sci. Total Environ., 45, 151 (1985).

37. K. Khan and H.M. Khan, Appl. Radiat. Isot., 54, 861 (2001).

38. S. Chinchon-Paya, B. Piedecausa, S. Hurtado, M.A. Sanjuan and S. Chinchon, Radiat. Meas., 46, 734 (2011).

39. M. Sharaf, M. Mansy, A.A. El Sayed and E. Abbas, Radiat. Meas., 31, 491 (1999).

40. A.O. Mustapha, D.G.S. Narayana, J.P. Patel and D. Otwoma, Radiat. Prot. Dosimetry, 71, 65 (1997).

41. M.I. Chowdhury, M.N. Alam and A.K.S. Ahmed, J. Radioanal. Nucl. Chem., 231, 117 (1998).

42. A. Malanca, V. Pessina and G. Dallara, Radiat. Prot. Dosimetry, 48, 199 (1993).

43. M. Iqbal, M. Tufail and S.M. Mirza, J. Environ. Radioact., 51, 255 (2000).

44. S. Turhan, U.N. Baykan and K. Sen, J. Radiol. Prot., 28, 83 (2008).

45. L. Xinwei, Radiat. Meas., 40, 94 (2005).

46. R.H. Higgy, M.S. El-Tahawy, A.T. Abdel-Fattah and U.A. Al-Akabawy, J. Environ. Radioact., 50, 253 (2000).

47. J.A. Ademola and P.O. Oguneletu, J. Environ. Radioact., 81, 107 (2005).

48. J.A. Ademola and I.P. Farai, Radiat. Prot. Dosimetry, 121, 395 (2006).

49. N. Ibrahim, J. Environ. Radioact., 43, 255 (1999). 